\title{
Cell cycle abnormality is a cellular phenotype in OCD
}

Running title: Abnormal cell cycle in OCD

Pravallika Manjappa ${ }^{1}$, Srinivas Balachander ${ }^{2,3}$, Safoora Naaz ${ }^{1,3}$, Ravi Kumar Nadella ${ }^{2,3}$, Tulika Shukla $^{2}$, Pradip Paul ${ }^{1,3}$, Meera Purushottam ${ }^{1,2,3}$, YC Janardhan Reddy ${ }^{2,3}$, Sanjeev Jain ${ }^{1,3}$, Biju Viswanath $^{1,2,3 \#}$, Reeteka Sud ${ }^{1,3 \#}$

(\# Co-corresponding authors)

\section{Affiliations}

${ }^{1}$ Molecular Genetics Lab, Department of Psychiatry,

${ }^{2}$ Obsessive-Compulsive Disorder Clinic, Department of Psychiatry,

${ }^{3}$ Accelerator Program for Discovery in Brain disorders using Stem cells (ADBS)

National Institute of Mental Health \& Neuro Sciences (NIMHANS), Bangalore, India

\section{Author Note}

Srinivas Balachander https://orcid.org/0000-0001-6729-6414

Reeteka Sud http://orcid.org/0000-0002-7866-6983

Biju Viswanath https://orcid.org/0000-0002-7317-1789

Pravallika Manjappa is currently affiliated to the BonePainII Innovative Training Network Neuroscience, BioPharmaceuticals R\&D, AstraZeneca, Cambridge, United Kingdom; Tulika Shukla is currently affiliated to: Department of Psychiatry, All India Institute of Medical Sciences, New Delhi, India

\section{We have no conflicts of interest to disclose}


medRxiv preprint doi: https://doi.org/10.1101/2020.03.31.20041368; this version posted September 22, 2020. The copyright holder for this preprint (which was not certified by peer review) is the author/funder, who has granted medRxiv a license to display the preprint in perpetuity.

It is made available under a CC-BY-NC-ND 4.0 International license .

\section{Corresponding Authors:}

Dr. Reeteka Sud, Research Coordinator, ADBS Lab, Neurobiology Research Building, National Institute of Mental Health \& Neuro Sciences (NIMHANS), Bangalore. Email:

reeteka@gmail.com. Phone: +919783137159

Dr. Biju Viswanath, Associate Professor, Department of Psychiatry, Hombegowda Nagar, Hosur Road, National Institute of Mental Health \& Neuro Sciences (NIMHANS), Bangalore. Email: bijuv1@gmail.com. Phone: +919480829594

Conflicts of Interest: Nil

\section{Acknowledgements:}

This work was supported by "Accelerator program for discovery in brain disorders using stem cells" (BT/PR17316/MED/31/326/2015) (ADBS) from Department of Biotechnology (DBT) and Pratiksha Trust; and SCIENCE \& ENGINEERING RESEARCH BOARD (SERB) project "Dissecting the biology of lithium response in human induced pluripotent stem cell derived neurons from patients with bipolar affective disorder" (FILE NO. ECR/2016/002076). 
medRxiv preprint doi: https://doi.org/10.1101/2020.03.31.20041368; this version posted September 22, 2020. The copyright holder for this preprint (which was not certified by peer review) is the author/funder, who has granted medRxiv a license to display the preprint in perpetuity.

It is made available under a CC-BY-NC-ND 4.0 International license .

\section{$\underline{\text { Abstract }}$}

Abnormal indices of cell cycle regulation have been reported in multiple psychiatric disorders. Though reports specific to obsessive compulsive disorder (OCD) are scant, numerous studies have highlighted partly common underlying biology in psychiatric disorders, cell cycle regulation being one such process. In this study, we therefore aimed to explore cell cycle in OCD. To the best of our knowledge, this is the first study to investigate these effects in OCD. We also evaluated the effect of in vitro fluoxetine, commonly used serotonin reuptake inhibitor (SRI) in OCD patients, on cell cycle regulation. The effects of both disease (OCD) and treatment (SRI) were assessed using lymphoblastoid cell lines (LCLs), derived from OCD patients and healthy controls, as a model system. LCLs were treated with $10 \mu \mathrm{M}$ of fluoxetine for 24 hours, and the percentage of cells in each phase of the cell cycle was determined by flow cytometry. We observed a lower proportion of cells in the G2/M phase in OCD cases than controls. The findings suggest that cell cycle dysregulation could be peripheral cellular phenotype for OCD. Among cases, all of whom had been systematically characterized for SRI treatment response, LCLs from non-responders to SRI treatment had a lower proportion of cells in G2/M phase than responders.

Keywords: OCD, cell cycle, fluoxetine, lymphoblastoid cells 
medRxiv preprint doi: https://doi.org/10.1101/2020.03.31.20041368; this version posted September 22, 2020. The copyright holder for this preprint (which was not certified by peer review) is the author/funder, who has granted medRxiv a license to display the preprint in perpetuity.

It is made available under a CC-BY-NC-ND 4.0 International license .

\section{Introduction}

Characterized by obsessions (intrusive, unwanted thoughts) and compulsions (performing highly ritualized behaviours intended to neutralize negative thoughts and emotions resulting from the obsessions), Obsessive Compulsive Disorder (OCD) is a common psychiatric disorder affecting almost $2 \%$ of the general population. Selective serotonin reuptake inhibitors (SRIs) form the mainstay of treatment, but many patients fail to gain therapeutic benefit (Goddard, Shekhar, Whiteman, \& Mcdougle, 2008). Clearly, cellular parameters that can serve as biomarkers for OCD, associated with the disease as well as treatment response, are critically needed.

Fluoxetine is a commonly used SRI in the treatment of OCD and influences many cellular parameters, including cell proliferation (Serafeim et al., 2003; Volpe, Ellison, Parchment, Grieshaber, \& Faustino, 2003). A recent study reported an increase in the proportion of G0/G1 mouse hippocampal neurons, along with a reduction of G2/M and S phase cells at 48 hrs and 96 hrs of treatment with fluoxetine (Solek et al., 2019). SRIs act through serotonin and dopamine transporters (Lima \& Urbina, 2002; Sanders-bush, Hazelwood, 2003), and influence serotonin receptors (Gladkevich, Kauffman, \& Korf, 2004); both of which are expressed on lymphocytes. Our lab, and others, have used lymphoblastoid cell lines (LCLs) (derived from lymphocytes) to study cell cycle regulation and cell proliferation, and the effect of SRI response in neuropsychiatric disorders (Breitfeld et al., 2016; Breitfeld, Scholl, Steffens, Laje, \& Stingl, 2017; Ashok et al., 2019; Paul et al., 2020).

Abnormal indices of cell cycle regulation have been reported in several psychiatric disorders. Though reports specific to OCD are scant, genomic findings have highlighted partly common 
medRxiv preprint doi: https://doi.org/10.1101/2020.03.31.20041368; this version posted September 22, 2020. The copyright holder for this preprint (which was not certified by peer review) is the author/funder, who has granted medRxiv a license to display the preprint in perpetuity.

It is made available under a CC-BY-NC-ND 4.0 International license .

underlying biology in psychiatric disorders (Vaidya et al. 2007; Wang et al. 2010; Ashok et al., 2019; Paul et al., 2020). Therefore, we examined the cell cycle in lymphocytes of patients with OCD and compared them with those of healthy controls. In addition, we wanted to examine if fluoxetine in vitro has a differential effect on cell cycle in OCD lymphocytes, based on clinical treatment response. 
medRxiv preprint doi: https://doi.org/10.1101/2020.03.31.20041368; this version posted September 22, 2020. The copyright holder for this preprint (which was not certified by peer review) is the author/funder, who has granted medRxiv a license to display the preprint in perpetuity.

It is made available under a CC-BY-NC-ND 4.0 International license .

\section{Materials and Methods}

\subsection{Subjects \& assessment of clinical treatment response}

All patients with OCD $(\mathrm{N}=11)$ were recruited from the Speciality OCD clinic of the National Institute of Mental Health and Neuro Sciences (NIMHANS, Bangalore). The Mini-International Neuropsychiatric Interview (MINI) and Yale-Brown Obsessive-Compulsive Scale (Y-BOCS) were used to diagnose and assess the patients clinically. Individuals ( $\mathrm{N}=8)$ with no personal and family history of psychiatric illnesses were age-matched with OCD patients and recruited as controls for the study. The study was approved by the Ethics Committee of NIMHANS. Prior to participation, informed written consent was taken. Among the patients, 5 had responded clinically to SRIs, whereas 3 did not. Three patients were partial responders and were excluded from the analysis of treatment response. Responders were those who had $>35 \%$ reduction in YBOCS (and CGI-I 1 or 2) following an SRI trial; non-responders were those with $<25 \%$ reduction (and CGI-I >3) even after at least 2 SRI trials (Mataix-Cols et al., 2016; Shukla et al., 2020). All patients were on treatment with SRIs at the time of sample collection.

\subsection{Generation and characterisation of LCLs}

Venous blood samples of patients and controls were collected to isolate peripheral blood mononuclear cells (PBMCs) using SepMate ${ }^{\mathrm{TM}}$ kit (Stem Cell Technologies), using the protocol adapted from Ashok et al., 2019. LCLs were generated from PBMCs by transformation using Epstein-Barr virus (Jung, 2013). All cell lines were cultured in RPMI-1640 (HiMedia) medium containing $20 \%$ heat-inactivated fetal bovine serum (GIBCO) and 1\% Penicillin-Streptomycin (GIBCO); as suspension cultures in a humidified environment at $37^{\circ} \mathrm{C}$ and $5 \% \mathrm{CO}_{2}$. The cell lines 
medRxiv preprint doi: https://doi.org/10.1101/2020.03.31.20041368; this version posted September 22, 2020. The copyright holder for this preprint (which was not certified by peer review) is the author/funder, who has granted medRxiv a license to display the preprint in perpetuity.

It is made available under a CC-BY-NC-ND 4.0 International license .

used had a doubling time of 48-72 hours, and those between passages 3 and 10 were used for the study.

\subsection{Fluoxetine treatment and cell cycle analysis}

LCLs were plated at a density of $10^{6}$ cells $/ \mathrm{ml}$ and treated in vitro with vehicle or $10 \mu \mathrm{M}$ Fluoxetine (Sigma) for 24 hours after which they were pelleted, washed with $1 \mathrm{X}$ phosphate buffer saline (PBS), fixed with $70 \%$ ethanol and stored at $4^{\circ} \mathrm{C}$ for a minimum of 24 hours. Fixed cells were washed and incubated for 30 min at $37^{\circ} \mathrm{C}$ in $1 \mathrm{X}$ PBS solution containing RNase

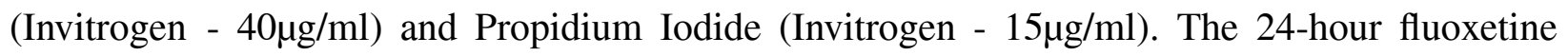
treatment protocol was adapted from Porton et al., 2013. Immunophenotyping of LCLs was performed, which showed that they were positive for CD19 (B cell marker) and negative for CD3 (T cell marker) and CD56 (NK cell marker). The experiment was performed in triplicates for each cell line.

Cell cycle analysis was performed by flow cytometry to estimate the proportion of cells in different phases of the cell cycle - G0/G1, S, and G2/M. The percentage of cells in each cell cycle phase was determined using the software FloJo (V10). The scatter plot was gated to include only singlet cells for analysis.

\subsection{Statistical analysis}

Statistical analysis was performed using GraphPad Prism (Version 8.2.1) and R (base packages, version 3.6.2). A $2 \times 2$ mixed model ANOVA with post-hoc pairwise comparisons (Tukey's HSD) were used to compare the different conditions, groups \& their interaction. All values $<0.05$ were considered significant. 
medRxiv preprint doi: https://doi.org/10.1101/2020.03.31.20041368; this version posted September 22, 2020. The copyright holder for this preprint (which was not certified by peer review) is the author/funder, who has granted medRxiv a license to display the preprint in perpetuity.

It is made available under a CC-BY-NC-ND 4.0 International license .

\section{Results}

\subsection{G2/M phase of cell cycle showed differences in control vs OCD cases}

Cell cycle analysis in LCLs (vehicle- and fluoxetine-treated) from 8 control and 11 OCD patients was performed and analysed using flow cytometry. Distribution of cells in G0/G1, S and G2/M phases of the cell cycle was determined by propidium iodide staining.

As shown in Table 1, the main effects of "group" and "treatment with fluoxetine" were significant predictors for the percentage of cells, but only for the G2/M phase. The estimated marginal means (EMM) with 95\% confidence intervals for cases vs controls was 11.8 (10.5-13.1) vs $14.1(12.8-15.3), \mathrm{F}(1,17)=6.88 \& \mathrm{p}=0.017$; and for vehicle vs fluoxetine-treated lines was 14.1 $(12.8-15.3)$ vs $11.7(10.5-13.0), \mathrm{F}(1.17)=5.97 \& \mathrm{p}=0.026$. Their interaction (Group * Treatment) was not significant, indicating that the effect of fluoxetine treatment was the same in LCLs from OCD cases and healthy controls. These findings are similar to other studies (Lin et al., 2016; Solek et al., 2019). There were no other significant differences in the post hoc comparisons performed using Tukey's HSD method (Table 2).

\subsection{Cell cycle from SRI-nonresponders showed decreased proliferative capacity}

Comparing among OCD cases, we found LCLs from clinical non-responders to SRI treatment had a significantly lower percentage of cells in the G2/M phase compared to treatment responders $(10.131 .56$ vs $13.781 .70, \mathrm{t}=-3.088, \mathrm{p}=0.023)$. No significant difference was found in the percentage of cells in other phases of the cell cycle, either between the groups or within groups, with or without in vitro fluoxetine (Table 1, Figure 1). 
medRxiv preprint doi: https://doi.org/10.1101/2020.03.31.20041368; this version posted September 22, 2020. The copyright holder for this preprint (which was not certified by peer review) is the author/funder, who has granted medRxiv a license to display the preprint in perpetuity.

It is made available under a CC-BY-NC-ND 4.0 International license .

Previous studies have shown fluoxetine reduces the number of cells in the G2/M and $\mathrm{S}$ phase (Lin et al., 2016; Solek et al., 2019). These effects were evident at 24 hrs with 10uM fluoxetine, which was the reason for choosing these parameters for the present study. Following in vitro fluoxetine treatment $(10 \mu \mathrm{M}$ for $24 \mathrm{hrs})$, we observed an overall reduction in the proportion of cells in the G2/M phase in cases and controls LCLs. The in vitro effects of fluoxetine need further exploration with a longer duration of treatment and larger sample numbers. 
medRxiv preprint doi: https://doi.org/10.1101/2020.03.31.20041368; this version posted September 22, 2020. The copyright holder for this preprint (which was not certified by peer review) is the author/funder, who has granted medRxiv a license to display the preprint in perpetuity.

It is made available under a CC-BY-NC-ND 4.0 International license .

\section{Discussion}

A critical and yet unanswered question in Psychiatry is how might clinical phenotypes manifest in terms of cellular readouts. Such objective biomarkers will help bring about a better understanding of psychiatric disorders, which thus far are principally known in terms of clinical signs and symptoms. The present study was undertaken with this overarching aim as our guiding principle.

The primary finding in this study is that there is a reduction in the number of proliferative LCLs from OCD cases. Since the number of cells in other phases of cell cycle is the same across experimental paradigms, the reduction in $\mathrm{G} 2 / \mathrm{M}$ phases could indicate cell cycle arrest. Physiologically, dividing cells undergo cell cycle arrest at this stage if DNA damage is detected. Though we did not probe for DNA damage in these LCLs, interestingly, Alici et al. (2016) did demonstrate oxidative DNA damage in peripheral blood in OCD patients.

An obvious next question is how might a finding in peripheral blood, or cell type derived from peripheral blood (LCL) be representative of mechanisms related to a brain disorder. Considering that brain biopsies from patients are not a realistic option, lymphocytes are a convenient model system in which to probe cellular functions. Substantial literature already exists to corroborate this principle for bipolar disorder (reviewed in Viswanath et al. 2015); though comparable evidence is largely wanting for OCD. Given that there are overlaps in cellular mechanisms related to severe mental illnesses, we wanted to see if LCLs derived from OCD patients display abnormal cellular phenotype. Disturbances in cell cycle, as we report here in OCD, have earlier also been reported for depression (Vaidya et al. 2007), schizophrenia (Wang et al. 2010, Ashok et 
medRxiv preprint doi: https://doi.org/10.1101/2020.03.31.20041368; this version posted September 22, 2020. The copyright holder for this preprint (which was not certified by peer review) is the author/funder, who has granted medRxiv a license to display the preprint in perpetuity.

It is made available under a CC-BY-NC-ND 4.0 International license .

al., 2019) and bipolar disorder (Paul et al., 2020). Collectively, this suggests that cell cycle dysregulation is a common molecular phenotype across clinically diverse psychiatric disorders. 


\section{$\underline{\text { References }}$}

Alici, D., Bulbul, F., Virit, O., Unal, A., Altindag, A., Alpak, G., Alici, H., Ermis, B., Mustafa, O., Taysi, S., Savas, H. (2016). Evaluation of oxidative metabolism and oxidative DNA damage in patients with obsessive compulsive disorder. Psychiatry and Clinical Neurosciences, 70, 109-115. doi:10.1111/pcn.12362

Ashok, A., Naaz, S., Kota, L. N., Sen, S., Purushottam, M., Faruq, M., ... Viswanath, B. (2019). Does retinoic acid reverse cell cycle dysregulation in Alzheimer's disease lymphocytes? Asian Journal of Psychiatry, 39, 174-177. https://doi.org/10.1016/j.ajp.2018.08.010

Breitfeld, J., Scholl, C., Steffens, M., Brandenburg, K., Probst-Schendzielorz, K., ... Stingl, J. C. (2016). Proliferation rates and gene expression profiles in human lymphoblastoid cell lines from patients with depression characterized in response to antidepressant drug therapy. Translational Psychiatry, 6, e950. https://doi.org/10.1038/tp.2016.185

Breitfeld, J., Scholl, C., Steffens, M., Laje, G., \& Stingl, J. C. (2017). Gene expression and proliferation biomarkers for antidepressant treatment resistance. Translational Psychiatry, 7, e1061-7. https://doi.org/10.1038/tp.2017.16

Fazzino, F., Montes, C., Urbina, M., Carreira, I., \& Lima, L. (2008). Serotonin transporter is differentially localized in subpopulations of lymphocytes of major depression patients. Effect of fluoxetine on proliferation. Journal of Neuroimmunology, 196, 173-180. https://doi.org/10.1016/j.jneuroim.2008.03.012

Gladkevich, A., Kauffman, H. F., \& Korf, J. (2004). Lymphocytes as a neural probe: Potential for studying psychiatric disorders. Progress in Neuro-Psychopharmacology and Biological Psychiatry, 28, 559-576. https://doi.org/10.1016/j.pnpbp.2004.01.009

Goddard, A. W., Shekhar, A., Whiteman, A. F., \& Mcdougle, C. J. (2008). Serotoninergic mechanisms in the treatment of obsessive-compulsive disorder. Drug Discov Today, 13, 325-32. https://doi.org/10.1016/j.drudis.2007.12.009

Hoose, S. A., Duran, C., Malik, I., Eslamfam, S., Shasserre, S. C., Downing, S. S., ... Polymenis, M. (2012). Systematic analysis of cell cycle effects of common drugs leads to the discovery of a 
medRxiv preprint doi: https://doi.org/10.1101/2020.03.31.20041368; this version posted September 22, 2020. The copyright holder for this preprint (which was not certified by peer review) is the author/funder, who has granted medRxiv a license to display the preprint in perpetuity.

It is made available under a CC-BY-NC-ND 4.0 International license .

suppressive interaction between gemfibrozil and fluoxetine. PLoS ONE, 7, 1-9. https://doi.org/10.1371/journal.pone.0036503

Lima, L., \& Urbina, M. (2002). Serotonin transporter modulation in blood lymphocytes from patients with major depression. Cellular and Molecular Neurobiology, 22, 797-804. https://doi.org/10.1023/A:1021869310702

Lin, Y. M., Yu, B. C., Chiu, W. T., Sun, H. Y., Chien, Y. C., Su, H. C., ... Tsao, C. W. (2016). Fluoxetine regulates cell growth inhibition of interferon- $\alpha$. International Journal of Oncology, 49, 1746-1754. https://doi.org/10.3892/ijo.2016.3650

Mataix-Cols, D., Fernandez de La Cruz, L., Nordsletten, A. E., Lenhard, F., Isomura, K., \& Simpson, H. B. (2016). Towards an international expert consensus for defining treatment response, remission, recovery and relapse in obsessive-compulsive disorder. World Psychiatry, 15, 80-81. https://doi.org/10.1002/wps.20299

Morag, A., Kirchheiner, J., Rehavi, M., \& Gurwitz, D. (2010). Human lymphoblastoid cell line panels: Novel tools for assessing shared drug pathways. Pharmacogenomics, 11, 327-340. https://doi.org/10.2217/pgs.10.27

Morag, A., Oron-karni, V., Rehavi, M., Stingl, J. C., \& Gurwitz, D. (2010). Genome-wide expression profiling of human lymphoblastoid cell lines identifies CHL1 as a putative SSRI antidepressant response biomarker. Pharmacogenomics, 12, 171-184. https://doi.org/10.2217/pgs.10.185

Paul, P., Iyer, S., Nadella, R., Nayak, R., ....Viswanath, B. (2020). Lithium response in bipolar disorder correlates with improved cell viability of patient derived cell lines. Scientific Reports 10, 7428. https://doi.org/10.1038/s41598-020-64202-1

Porton, B., Greenberg, B. D., Askland, K., Serra, L. M., Gesmonde, J., Rudnick, G., ... Kao, H. T. (2013). Isoforms of the neuronal glutamate transporter gene, SLC1A1/EAAC1, negatively modulate glutamate uptake: Relevance to obsessive-compulsive disorder. Translational Psychiatry, 3, e259. https://doi.org/10.1038/tp.2013.35 
Sanders-bush, E., \& Hazelwood, L. (2003). 5-hydroxytryptamine (Serotonin) and Dopamine. Goodman \& Gilman's: The Pharmacological Basis of Therapeutics, 12e (pp. 1-37).

Serafeim, A., Holder, M. J., Grafton, G., Chamba, A., Drayson, M. T., Luong, Q. T., ... Gordon, J. (2003). Selective serotonin reuptake inhibitors directly signal for apoptosis in biopsy-like Burkitt lymphoma cells. Blood, 101, 3212-3219. https://doi.org/10.1182/blood-2002-07-2044

Shukla, T., Nadella, R. K., Taj M J, R. J., Ganesh, S., Nestadt, G., Purushottam, M., ... Viswanath, B. (2020). Association of SLC1A1 gene polymorphism with obsessive compulsive disorder in a sample from southern India. Experimental and Clinical Psychopharmacology, https://doi.org/10.1037/pha0000348. Online ahead of Print.

Solek, P., Koszla, O., Mytych, J., Badura, J., Chelminiak, Z., Cuprys, M., ... Koziorowski, M. (2019). Neuronal life or death linked to depression treatment: the interplay between drugs and their stress-related outcomes relate to single or combined drug therapies. Apoptosis, 24(9-10), 773-784. https://doi.org/10.1007/s10495-019-01557-5

Volpe, D. A., Ellison, C. D., Parchment, R. E., Grieshaber, C. K., \& Faustino, P. J. (2003). Effects of amitriptyline and fluoxetine upon the in vitro proliferation of tumor cell lines. Journal of Experimental Therapeutics and Oncology, 3, 169-184. https://doi.org/10.1046/j.1359-4117.2003.01091.x

Vidita A Vaidya, Kimberly Fernandes, Shanker Jha. Regulation of Adult Hippocampal Neurogenesis: Relevance to Depression. Expert Rev Neurother 2007, 7,853-64. doi: 10.1586/14737175.7.7.853.

L Wang, H E Lockstone, P C Guest, Y Levin, A Palotás, S Pietsch, E Schwarz, H Rahmoune, L W Harris, D Ma, S Bahn. Expression Profiling of Fibroblasts Identifies Cell Cycle Abnormalities in Schizophrenia. J Proteome Res 2010, 9, 521-7. doi: 10.1021/pr900867x. 
medRxiv preprint doi: https://doi.org/10.1101/2020.03.31.20041368; this version posted September 22, 2020. The copyright holder for this preprint (which was not certified by peer review) is the author/funder, who has granted medRxiv a license to display the preprint in perpetuity.

It is made available under a CC-BY-NC-ND 4.0 International license .

Table 1: Results of $2 \times 2$ Mixed ANOVA comparing cell lines from cases $(n=11)$ vs controls $(\mathrm{n}=8)$, with and without treatment with fluoxetine

\begin{tabular}{|c|c|c|c|c|c|c|}
\hline & \multicolumn{2}{|c|}{ G0/G1 Phase } & \multicolumn{2}{c|}{ S Phase } & \multicolumn{2}{c|}{ G2/M Phase } \\
\cline { 2 - 7 } & $\mathrm{F}$ & $\mathrm{p}$-value & $\mathrm{F}$ & $\mathrm{p}$-value & $\mathrm{F}$ & $\mathrm{p}$-value \\
& & & & & & \\
\hline Group $(0=$ Control, 1=Case $)$ & 0.002 & 0.963 & 0.003 & 0.958 & 6.988 & 0.0171 \\
\hline Fluoxetine Treatment & & & & & & \\
$(0=$ Untreated; 1=Treated $)$ & 2.511 & 0.131 & 0.078 & 0.783 & 5.967 & 0.0258 \\
\hline Group*Fluoxetine & & & & & & \\
Treatment Interaction & 0.679 & 0.421 & 1.623 & 0.22 & 1.272 & 0.2751 \\
\hline
\end{tabular}


medRxiv preprint doi: https://doi.org/10.1101/2020.03.31.20041368; this version posted September 22, 2020. The copyright holder for this preprint (which was not certified by peer review) is the author/funder, who has granted medRxiv a license to display the preprint in perpetuity.

It is made available under a CC-BY-NC-ND 4.0 International license .

Table 2: Post Hoc Test (Tukey's HSD) for the Percentage of cells in G2/M Phase

\begin{tabular}{|c|c|c|c|c|}
\hline \multirow[b]{2}{*}{ Pairwise Contrast } & \multirow{2}{*}{$\begin{array}{c}\text { Mean } \\
\text { Difference }\end{array}$} & \multicolumn{2}{|c|}{$\begin{array}{c}\text { 95\% Confidence } \\
\text { Intervals }\end{array}$} & \multirow{2}{*}{$\begin{array}{l}\text { Adjuste } \\
\quad \text { d } \\
\text { P-Value }\end{array}$} \\
\hline & & Lower & Upper & \\
\hline Treated:Case - Untreated:Case & -1.315 & -4.400 & 1.769 & 0.661 \\
\hline Untreated:Control - Untreated:Case & 3.288 & -0.073 & 6.650 & 0.057 \\
\hline Treated:Control - Untreated:Case & -0.055 & -3.417 & 3.306 & 1.000 \\
\hline Untreated:Control - Treated:Case & 4.604 & 1.242 & 7.965 & 0.004 \\
\hline Treated:Control - Treated:Case & 1.260 & -2.102 & 4.621 & 0.743 \\
\hline Treated:Control - Untreated:Control & -3.344 & -6.961 & 0.273 & 0.078 \\
\hline
\end{tabular}


medRxiv preprint doi: https://doi.org/10.1101/2020.03.31.20041368; this version posted September 22, 2020. The copyright holder for this preprint (which was not certified by peer review) is the author/funder, who has granted medRxiv a license to display the preprint in perpetuity.

It is made available under a CC-BY-NC-ND 4.0 International license .

Figure 1. Difference between clinical treatment responders $(n=5)$ and non-responders $(n=3)$ in the percentage of LCLs in each phase of the cell cycle, with and without fluoxetine treatment

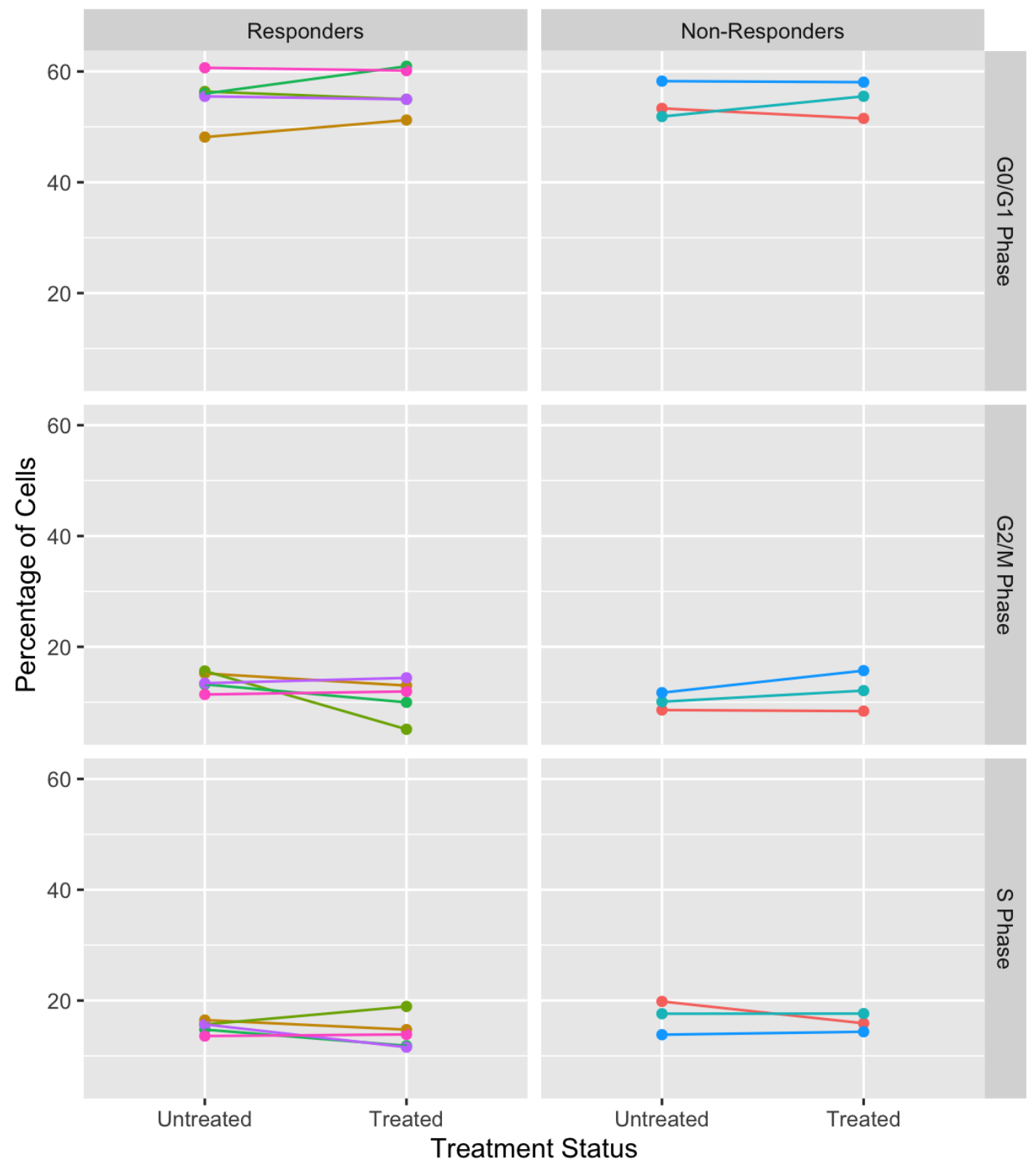

